\title{
Flow cytometric cell cycle analysis of cultured brown bear fibroblast cells
}

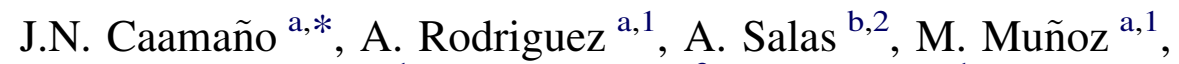 \\ C. Diez ${ }^{\mathrm{a}, 1}$, R.S. Prather ${ }^{\mathrm{c}, 3}$, E. Gómez ${ }^{\mathrm{a}, 1}$ \\ ${ }^{a}$ Area de Genética y Reproducción, SERIDA, Camino de los Claveles 604, 33203 Gijón, Principado de Asturias, Spain \\ ${ }^{\mathrm{b}}$ Servicios Científico-Técnicos, Universidad de Oviedo, c/Julián Clavería, 33006 Oviedo, Asturias, Spain \\ ${ }^{\mathrm{c}}$ Division of Animal Science, University of Missouri, Columbia, MO 65211, USA
}

Received 9 October 2007; revised 13 November 2007; accepted 25 February 2008

\begin{abstract}
The aim of this study was to assess by flow cytometry the cell cycle of brown bear fibroblast cells cultured under different growth conditions. Skin biopsies were taken in Cantabria (Spain) from a live, anaesthetized brown bear. DNA analysis was performed by flow cytometry following cell DNA staining with propidium iodide. Serum starvation increased $(P<0.01)$ the percentage of G0/G1 phase cells $(92.7 \pm 0.86)$ as compared to cycling cells $(39.7 \pm 0.86)$ or cells cultured to confluency $(87.3 \pm 0.86)$. DMSO included for $48 \mathrm{~h}$ in the culture significantly increased $(P<0.01)$ the percentage of G0/G1 phase of the cell cycle at all concentrations used and decreased percentages of S phase in a dose-dependent fashion. Roscovitine increased the G0/G1 phase of the cell cycle $(P<0.01)$ at $15 \mu \mathrm{M}$ concentration. Interestingly, the G2/M stage significantly increased at 30 and $50 \mu \mathrm{M}$ compared to the control and $15 \mu \mathrm{M}(P<0.02)$. The cell cycle of brown bear adult fibroblast cells can be successfully synchronized under a variety of culture conditions.
\end{abstract}

(C) 2008 International Federation for Cell Biology. Published by Elsevier Ltd. All rights reserved.

Keywords: Brown bear; Cell cycle; Flow cytometry; DMSO; Roscovitine

\section{Introduction}

Assisted reproductive technologies have been used to help in the preservation of endangered or threatened animals such as the African wild cat (Gomez et al., 2003) and giant panda (Han et al., 2003; Spindler et al., 2004; Hori et al., 2006). Although nuclear transfer raises controversial questions in its applications to wildlife conservation (Holt et al., 2004), the potential of this technology as a valuable tool for aiding in

\footnotetext{
* Corresponding author. Tel.: +34 9851953 00; fax: +34 985195310 .

E-mail addresses: jncaamano@serida.org (J.N. Caamaño), airodriguez@ serida.org (A. Rodriguez), ana@spi.uniovi.es (A. Salas), mmunoz@serida. org (M. Muñoz), mcdiez@serida.org (C. Diez), PratherR@missouri.edu (R.S. Prather), egomez@serida.org (E. Gómez).

${ }^{1}$ Tel.: +34 9851953 00; fax: +34985195310.

2 Tel.: +34985103660.

3 Tel.: +1 5738827446 .
}

the conservation of some endangered and threatened animals should not be ignored. In Spain, the Cantabric brown bear (Ursus arctos pyrenaicus) is at risk of extinction with a population estimated at only 100 animals. Efforts have been made to protect the declining environmental conditions and to preserve semen, cells and somatic tissues.

When populations or sub-population are at risk of extinction, nuclear transfer may be a valuable approach for species restoration (Gomez et al., 2006). Somatic cell nuclear transfer (SCNT) has been successfully applied in domestic and laboratory animals and in wild animals (Gomez et al., 2003; Loi et al., 2001; Williams et al., 2006). The control of cell cycle stage of donor cells is a relevant factor in the development of SCNT embryos. Differences in DNA content of donor nuclei vary according to the phase of the cell cycle and may affect the interaction with the recipient cytoplasts. Researchers have used different approaches to synchronize the cell cycle of the donor cells, among them, cell confluency-contact inhibition 
(Hinrichs et al., 2006) and serum starvation (Li et al., 2003). In addition, chemical inhibitors have been used such as roscovitine (Gibbons et al., 2002), dimethyl sulfoxide (DMSO) (Hashem et al., 2007), butyrolactone I (Kues et al., 2000), aphidicolin (Collas et al., 1992), demecolcine (Li et al., 2005), Hoechst 33342 (Kühholzer and Prather, 2001), mimosine (Vacková et al., 2003) or colchicine (Lai et al., 2001) that result in cell cycle arrest at specific points. However, no work has been done on the control of the cell cycle stages in brown bear. The aim of this study was to assess by flow cytometry the cell cycle of brown bear fibroblast cells cultured under a variety of cell cycle-arresting treatments.

\section{Materials and methods}

\subsection{Establishment and culture of fibroblast cells}

Skin biopsies were taken in Cantabria (Spain) from a live, anaesthetized brown bear (Ursus arctos). A procedure to obtain culture and cryopreserve skin-derived fibroblasts from brown bears has been described (Caamaño et al., 2005). Briefly, two skin biopsies were taken from the inner thigh. Biopsies were manually cut into small pieces, mixed together and enzymatically digested with collagenase Type IV (300 units/mL) (Sigma C5138) for $14 \mathrm{~h}$ at $38^{\circ} \mathrm{C}$. Disaggregated cells were centrifuged at $1600 \mathrm{rpm}$ for $10 \mathrm{~min}$ and the pellet was diluted with D-MEM (Sigma D5671) containing 10\% Fetal Bovine Serum (FBS). Cells were placed in a $25 \mathrm{~cm}^{2}$ flask for culture under $5 \% \mathrm{CO}_{2}$ in air and high humidity at $38{ }^{\circ} \mathrm{C}$. Confluent fibroblast monolayer was obtained after five days in culture. Two to four passages were performed using $75 \mathrm{~cm}^{2}$ flasks before freezing fibroblasts in D-MEM containing 10\% DMSO and $10 \%$ FBS.

\subsection{Flow cytometric analysis}

DNA content and cell cycle analysis were performed by flow cytometry. Cell suspensions and DNA staining with propidium iodide were performed following an optimized method based on the Vindelöv technique (Vindelov et al., 1983). Samples were analyzed in a Cytomics FC-500 cytometer (Beckman Coulter). A total of 20,000 cells per sample were collected by using a $488 \mathrm{~nm}$ excitation and a $605-635 \mathrm{~nm}$ bandpass filter. Cells were gated on forward light scatter versus side light scatter such that only cells without debris were assayed. The DNA histogram analysis was performed prior to manual elimination of aggregates by Modfit LT 3.0 software (Verity Software House), and the percentages of cells existing within the various phases of the cell cycle were automatically calculated by the program with the same algorithm in all the samples.

\subsection{Cell treatments}

In experiment 1 , thawed fibroblast cells (second passage) were seeded in three $25 \mathrm{~cm}^{2}$ flasks $\left(8.5 \times 10^{5}\right.$ cells/flask $)$. After $24 \mathrm{~h}$ in culture, fibroblast cells were exposed to one of three treatments: (1) cells cultured to 70-80\% confluency (cycling cells), (2) cells cultured to $100 \%$ confluency and then cultured for an additional five days (contact inhibition) or (3) cells cultured in serum-starved conditions for five days.

Fibroblast cells were exposed to cell cycle inhibitors and dose-response experiments were performed for each of the chemicals, DMSO and roscovitine. In experiment 2, cells were seeded in four $75 \mathrm{~cm}^{2}$ flasks at a concentration of $1.25 \times$ $10^{6}$ cells/flask and cultured for $24 \mathrm{~h}$. The culture medium was removed and replaced with medium containing DMSO (Sigma D5879) at $0 \%, 1 \%, 2 \%$ or $3 \%$ for $48 \mathrm{~h}$. In experiment 3 , thawed fibroblast cells were seeded in four $75 \mathrm{~cm}^{2}$ flasks at a concentration of $1 \times 10^{6}$ cells/flask and cultured for $24 \mathrm{~h}$. The culture medium was removed and replaced with culture medium containing roscovitine (Sigma R7772) at a concentration of $0,15,30$, or $50 \mu \mathrm{M}$ and cultured for another $24 \mathrm{~h}$. In all the above experiments, cells were cultured under the same conditions $\left(5 \% \mathrm{CO}_{2}\right.$ in air and high humidity at $\left.38^{\circ} \mathrm{C}\right)$.

\subsection{Statistical analyses}

The above experiments were replicated three times. In each experiment, cells from each replicate were analyzed by flow cytometry on separate occasions. On each occasion, two samples of each treatment were analyzed $(n=6)$. Statistical analysis was performed by using the GLM procedure of SAS. Differences between treatments were determined by using LSM and were considered significant when $P<0.05$.

\section{Results}

In experiment 1 , the percentages of G0/G1 and $\mathrm{S}$ phase cells differed under different growth conditions. Serum starvation for five days increased $(P<0.01)$ the percentage of $\mathrm{G} 0 /$ G1 phase cells as compared to cycling cells or cells cultured to confluency. Cells cultured to $70-80 \%$ confluency contained higher $(P<0.01)$ percentages of $\mathrm{S}$ and $\mathrm{G} 2+\mathrm{M}$ cells compared to cells cultured to confluency or serum starved, respectively (Table 1 and Fig. 1).

Cell cycle inhibitors, DMSO and roscovitine, were added to the cultures in an attempt to synchronize adult fibroblast cells in G0/G1 phase of the cell cycle. In experiment 2, DMSO included for $48 \mathrm{~h}$ in culture significantly increased $(P<0.01)$ the percentage of cells in G0/G1 phase at all concentrations used. However, only DMSO at $3 \%$ showed an

Table 1

Percentages $( \pm \mathrm{SD})$ of brown bear fibroblasts existing in the various phases of the cell cycle after treatment with different growth conditions

\begin{tabular}{|c|c|c|c|}
\hline \multirow[t]{2}{*}{ Treatment } & \multicolumn{3}{|c|}{ Cell cycle phase } \\
\hline & G0/G1 & $\mathrm{S}$ & $\mathrm{G} 2 / \mathrm{M}$ \\
\hline $70 \%$ Confluency & $39.6 \pm 3.4^{\mathrm{a}}$ & $35.1 \pm 2.3^{\mathrm{a}}$ & $25.2 \pm 4.4^{\mathrm{a}}$ \\
\hline $\begin{array}{l}\text { 100\% Confluency } \\
\text { (contact inhibition) }\end{array}$ & $87.2 \pm 1.0^{\mathrm{b}}$ & $8.3 \pm 2.1^{b}$ & $4.4 \pm 1.1^{\mathrm{b}}$ \\
\hline Serum-starved & $92.7 \pm 0.9^{c}$ & $1.7 \pm 0.4^{\mathrm{c}}$ & $5.5 \pm 0.8^{b}$ \\
\hline
\end{tabular}


1) Cycling

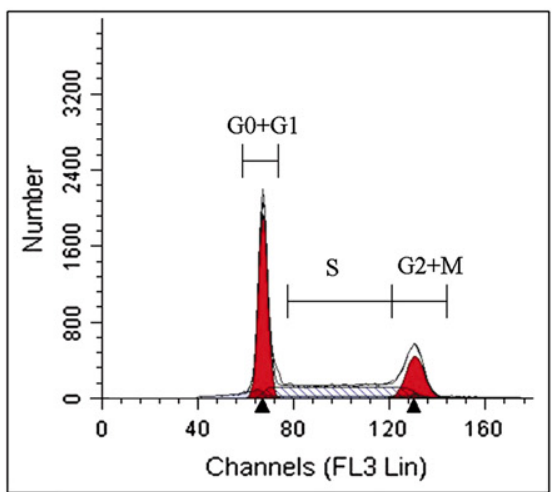

2) Contact inhibition

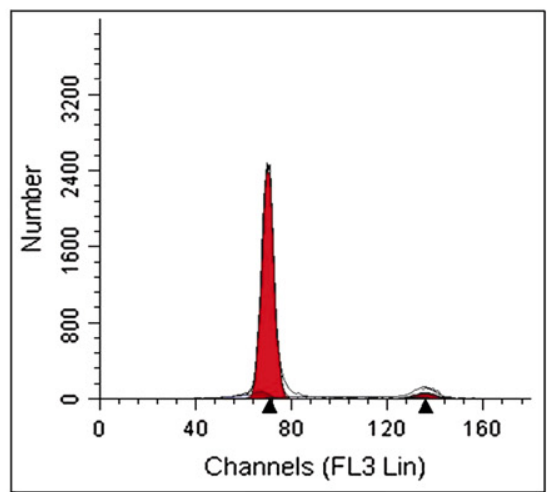

3) Serum-starved

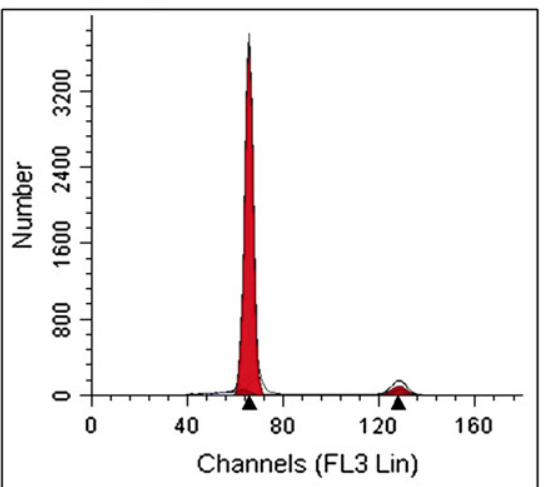

Fig. 1. Typical histograms of DNA obtained using flow cytometry of brown bear fibroblast cells cultured under different growth conditions.

increased percentage of cells in G2 stage $(P<0.01)$. DMSO decreased the percentages of $\mathrm{S}$ phase in a dose-dependent fashion (Table 2). Fig. 2 shows fibroblast cells cultured with $0 \%, 1 \%, 2 \%$ or $3 \%$ DMSO for $48 \mathrm{~h}$. DMSO at higher concentrations exerted a negative effect on total cell numbers (data not shown).

When roscovitine was added to the cultures in a doseresponse experiment, only $15 \mu \mathrm{M}$ significantly increased the percentage of cells in G0/G1 phase $(P<0.01)$, while the percentage of cells in $\mathrm{S}$ phase decreased at all concentrations used in this experiment compared to the control group $(P<0.01)$. Interestingly, roscovitine $(30$ and $50 \mu \mathrm{M})$ significantly increased the proportions of cells in $\mathrm{G} 2 / \mathrm{M}$ stage compared to $15 \mu \mathrm{M}$ and the control (Table 3).

\section{Discussion}

In this study, flow cytometry has allowed us to analyze the cell cycle characteristic of brown bear adult fibroblast cells under a variety of cell cycle-arresting treatments. Serum starvation and induction of a confluent monolayer elicited a higher percentage of cells in G0/G1 and a lower percentage of $\mathrm{S}$ and $\mathrm{G} 2 / \mathrm{M}$ stages than cycling cells. When taken in context of differences in cell types and animal species, the present results are in agreement with those of Gomez et al. (2003) in African wild cat and domestic cat, Boquest et al. (1999) in pig, Hayes et al. (2005) in cattle, Saikhun et al. (2004) in swamp buffalo, Han et al. (2003) in giant panda, Li et al. (2003) in ferret and Liu et al. (2004) in rabbit. Cultured adult fibroblasts from a Siberian tiger (Hashem et al., 2007) showed

Table 2

Percentage $( \pm \mathrm{SD})$ of brown bear fibroblast cells existing in the various phases of the cell cycle after treatment with different levels of DMSO for $48 \mathrm{~h}$

\begin{tabular}{llll}
\hline DMSO $(\%)$ & \multicolumn{3}{l}{ Cell cycle phase } \\
\cline { 2 - 4 } & G0/G1 & $\mathrm{S}$ & G2/M \\
\hline 0 & $71.0 \pm 0.9^{\mathrm{a}}$ & $17.8 \pm 1.3^{\mathrm{a}}$ & $11.1 \pm 0.4^{\mathrm{ab}}$ \\
1 & $79.1 \pm 0.8^{\mathrm{b}}$ & $10.6 \pm 0.8^{\mathrm{b}}$ & $10.2 \pm 0.3^{\mathrm{a}}$ \\
2 & $79.1 \pm 1.1^{\mathrm{b}}$ & $9.1 \pm 0.4^{\mathrm{b}}$ & $11.7 \pm 0.9^{\mathrm{b}}$ \\
3 & $79.0 \pm 2.1^{\mathrm{b}}$ & $5.2 \pm 1.6^{\mathrm{c}}$ & $15.6 \pm 0.8^{\mathrm{c}}$ \\
\hline a,b,c Values within a column having unlike superscripts are different $(P<0.01)$.
\end{tabular}

a similar trend in relation to G0/G1. However, the $\mathrm{S}$ and G2/M stages did not differ significantly in the cycling cells, serumstarved cells and confluent monolayer. In contrast, goral adult fibroblast cells did not show differences in the proportion of G0/G1 between treatments (Hashem et al., 2006). Moreover, a fully confluent monolayer produced higher proportion of $S$ and G2/M stages than serum starved and cycling cells. Differences in the results could be explained by differences in experimental protocols, animal species, cell type and number of passages used in the culture of fibroblasts.

Alternatively, cells can be arrested in the cell cycle by exposure to reversible cell cycle inhibitors such as DMSO and roscovitine. In this study, DMSO included for $48 \mathrm{~h}$ in culture significantly increased the percentage of cells in G0/G1 phase, while the percentage of cells in $\mathrm{S}$ stage decreased in a dosedependent fashion. DMSO did not affect the cell cycle stages of cultured skin fibroblasts of the Siberian tiger (Hashem et al., 2007). Culture of goral skin fibroblast with $0.5 \%$ and $1 \%$ DMSO for $24 \mathrm{~h}$ showed an increased percentage of cells in the G0/G1 stage (Hashem et al., 2006). However, 2.5\% DMSO used for either 4 or $24 \mathrm{~h}$ also has an effect on goral fibroblast cells, decreasing the percentage in G0/G1 and the $\mathrm{G} 2 / \mathrm{M}$ stages. These apparently contradictory results may depend on concentration of DMSO used or species sensitivity to this chemical. Roscovitine has been effective in arresting the cell cycle in mammals (Mermillod et al., 2000). In bovine, Gibbons et al. (2002) showed that roscovitine improved cell cycle synchrony and the nuclear reprogramming capacity of granulosa cells at G0/G1 stage, resulting in enhanced fetal and calf survival and increased cloning efficiency. Roscovitine did not affect the proportion of cells in G0/G1 stage in horse (Hinrichs et al., 2006), while in African wild cats and domestic cats, a higher percentage of adult fibroblast cell nuclei was in the G0/G1 phase after roscovitine treatment (Gomez et al., 2003). In our study, roscovitine at lower concentration $(15 \mu \mathrm{M})$ increased the percentage of cells in $\mathrm{G} 0 / \mathrm{G} 1$ phase, while the percentage of cells in $\mathrm{S}$ phase decreased at all concentration used. In addition, the percentage of cells in G2/M stage increased with $30 \mu \mathrm{M}$ and $50 \mu \mathrm{M}$ roscovitine. One possible explanation of the effects of roscovitine showed under our experimental conditions is that roscovitine could have a preferential 

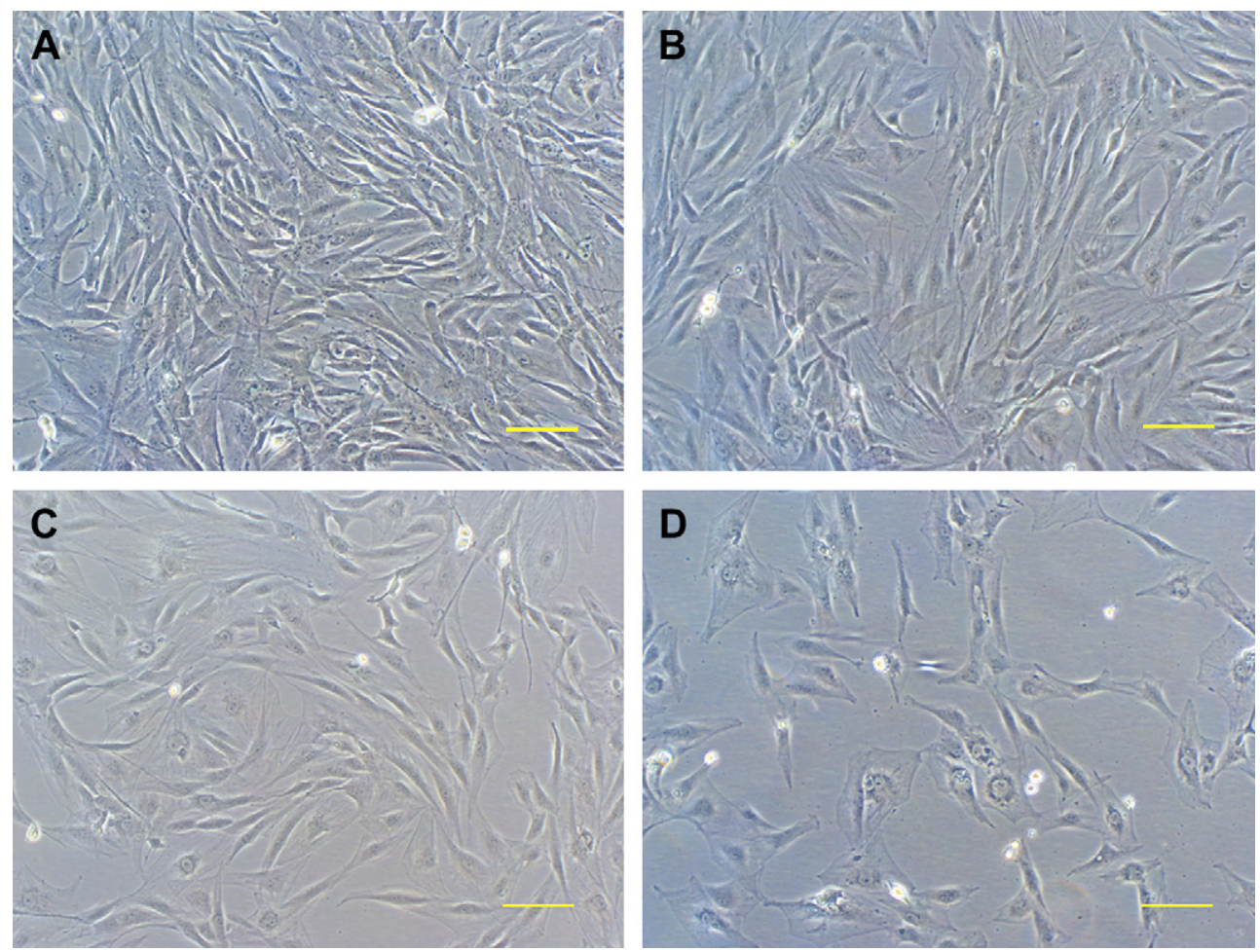

Fig. 2. Brown bear fibroblast cells cultured with 0 (A), 1 (B), 2 (C), or 3 (D) percentage of DMSO for $48 \mathrm{~h}(100 \times)$. Scale bar $=100 \mu \mathrm{m}$.

inhibition on a specific cyclin-dependent kinase (CDK) at lower concentrations, while it would need higher concentrations to affect other CDKs, such as observed with human fibroblasts (Alessi et al., 1998).

When a metaphase II oocyte with a high level of maturation promoting factor is used as a recipient ooplasm, a G0/G1 or pre-S phase donor nucleus is required (Campbell et al., 1996). Further research will be necessary and interspecies SCNT should be considered to assess nuclear reprogramming with brown bear fibroblasts. A careful evaluation of the outcome of using brown bear fibroblast cells exposed to chemical and non-chemical treatments for interspecies SCNT would be necessary before reaching a definite conclusion on which treatment would be the most adequate for embryo production. Several authors reported that serum starvation induced higher rates of DNA fragmentation (Boquest et al., 1999; Kues et al., 2000; Gibbons et al., 2002) which could lead to failure in nuclear reprogramming after NT. Some of the chemical treatments could also be detrimental to the cells such as DMSO in our experiment. DMSO seemed detrimental for brown bear

Table 3

Percentage ( \pm SD) of brown bear fibroblast cells existing in the various phases of the cell cycle after treatment with roscovitine for $24 \mathrm{~h}$

\begin{tabular}{llrl}
\hline $\begin{array}{l}\text { Roscovitine } \\
(\mu \mathrm{M})\end{array}$ & \multicolumn{3}{l}{ Cell cycle phase } \\
\cline { 2 - 4 } & $\mathrm{G} 0 / \mathrm{G} 1$ & $\mathrm{~S}$ & $\mathrm{G} 2 / \mathrm{M}$ \\
\hline 0 & $62.4 \pm 3.0^{\mathrm{a}}$ & $24.8 \pm 1.5^{\mathrm{a}}$ & $12.7 \pm 2.0^{\mathrm{a}}$ \\
15 & $76.4 \pm 5.9^{\mathrm{b}}$ & $8.5 \pm 1.9^{\mathrm{b}}$ & $15.1 \pm 4.6^{\mathrm{a}}$ \\
30 & $64.5 \pm 3.3^{\mathrm{a}}$ & $11.1 \pm 0.7^{\mathrm{c}}$ & $24.3 \pm 2.7^{\mathrm{b}}$ \\
50 & $67.1 \pm 3.4^{\mathrm{a}}$ & $9.5 \pm 0.7^{\mathrm{bc}}$ & $23.3 \pm 2.8^{\mathrm{b}}$ \\
\hline a,b,c & Values within a column having unlike superscripts are different $(P<0.02)$.
\end{tabular}

fibroblast cells at higher concentrations (2\% and 3\%). These results are not surprising, since DMSO could be toxic for the cells.

In conclusion, we used flow cytometry to assess the cell cycle characteristics of brown bear adult fibroblasts. The results of the present study indicate that the cell cycle of brown bear adult fibroblast cells can be successfully synchronized under a variety of culture conditions. Serum starvation, confluent monolayer, $1 \%$ DMSO and $15 \mu \mathrm{M}$ roscovitine have been shown to be effective in synchronizing brown bear fibroblasts in $\mathrm{G} 0 / \mathrm{G} 1$ stage of the cell cycle.

\section{Acknowledgments}

The authors thank and recognize Parque de la Naturaleza de Cabárceno, Cantabria, Spain for access and management of brown bears and Consejería de Medio Ambiente, Ordenación del Territorio e Infraestructuras, Asturias, Spain for grant support of this study. Project $\mathrm{N}^{\circ}$ MEC HH2005-0015.

\section{References}

Alessi F, Quarta S, Savio M, Riva F, Rossi L, Stivala LA, et al. The cyclindependent kinase inhibitors olomoucine and roscovitine arrest human fibroblasts in G1 phase by specific inhibition of CDK2 activity. Exp Cell Res 1998;245:8-18.

Boquest AC, Day BN, Prather RS. Flow cytometric cell cycle analysis of cultured porcine fetal fibroblast cells. Biol Reprod 1999;60:1013-9.

Caamaño JN, Hermsen M, Marcos J, Meana A, Alonso C, Goyache F, et al. A procedure to obtain fibroblasts from wild animals. Reprod Fertil Dev 2005;2:245. 
Campbell KHS, Loi P, Otaegui PJ, Wilmut I. Cell cycle co-ordination in embryo cloning by nuclear transfer. Rev Reprod 1996;1:40-6.

Collas P, Pinto-Correia C, Ponce de Leon FA, Robl JM. Effect of donor cell cycle stage on chromatin and spindle morphology in nuclear transplant rabbit embryos. Biol Reprod 1992;46:501-11.

Gibbons J, Arat S, Rzucidlo J, Miyoshi K, Waltenburg R, Respess D, et al. Enhanced survivability of cloned calves derived from roscovitine-treated adult somatic cells. Biol Reprod 2002;66(4):895-900.

Gomez MC, Jenkins JA, Giraldo A, Harris RF, King A, Dresser BL, et al. Nuclear transfer of synchronized African wild cat somatic cells into enucleated domestic cat oocytes. Biol Reprod 2003;69:1032-41.

Gomez MC, Pope CE, Dresser BL. Nuclear transfer in cats and its application. Theriogenology 2006;66(1):72-81.

Han ZM, Chen DY, Li JS, Sun QY, Wang PY, Du J, et al. Flow cytometric cellcycle analysis of cultured fibroblasts from the giant panda, Ailuropoda melanoleuca L. Cell Biol Int 2003;27:349-53.

Hashem MA, Bhandari DP, Kang SK, Lee BC. Cell cycle analysis and interspecies nuclear transfer of in vitro cultured skin fibroblasts of the Siberian tiger (Panthera tigris Altaica). Mol Reprod Dev 2007;74(4):403-11.

Hashem MA, Bhandari DP, Kang SK, Lee BC, Suk HW. Cell cycle analysis of in vitro cultured goral (Naemorhedus caudatus) adult skin fibroblasts. Cell Biol Int 2006;30(9):698-703.

Hayes O, Ramos B, Rodríguez LL, Aguilar A, Badía T, Castro FO. Cell confluency is as efficient as serum starvation for inducing arrest in the G0/G1 phase of the cell cycle in granulosa and fibroblast cells of cattle. Anim Reprod Sci 2005;87:181-92.

Hinrichs K, Choi YH, Love CC, Chung YG, Varner DD. Production of horse foals via direct injection of roscovitine-treated donor cells and activation by injection of sperm extract. Reproduction 2006;131:1063-72.

Holt WV, Pickard AR, Prather RS. Wildlife conservation and reproductive cloning. Reproduction 2004;127(3):317-24.

Hori T, Hashizaki F, Narushima E, Komiya T, Orima H, Tsutsui T. A trial of intrauterine insemination using a fiberscope in the giant panda (Ailuropoda melanoleuca). J Vet Med Sci 2006;68(9):987-90.

Kues WA, Anger M, Carnwath JW, Paul D, Motlik J, Niemann H. Cell cycle synchronization of porcine fetal fibroblasts: effects of serum deprivation and reversible cell cycle inhibitors. Biol Reprod 2000;2:412-9.
Kühholzer B, Prather RS. Synchronization of porcine fetal fibroblast cells with topoisomerase-inhibitor hoechst 33342. Anim Reprod Sci 2001;66:109-16.

Lai L, Tao T, Macháty Z, Kühholzer B, Sun Qing-Yuan, Park KwangWook, et al. Feasibility of producing porcine nuclear transfer embryos by using G2/M-stage fetal fibroblasts as donors. Biol Reprod 2001;65: 1558-64.

Li Z, Chen X, Sun X, Zhou Q, Chen J, Leno GH, et al. Nuclear transfer of Mphase ferret fibroblasts synchronized with the microtubule inhibitor demecolcine. J Exp Zool 2005;303(12):1126-34.

Li Z, Sabet MR, Zhou Q, Liu X, Ding W, Zhang Y, et al. Developmental capacity of ferret embryos by nuclear transfer using G0/G1-phase fetal fibroblasts. Biol Reprod 2003;68:2297-303.

Liu CT, Yu KC, Ju JC. Cell cycle stage analysis of rabbit foetal fibroblasts and cumulus cells. Reprod Domest Anim 2004;39:385-90.

Loi P, Ptak G, Barboni B, Fulka Jr J, Cappai P, Clinton M. Genetic rescue of an endangered mammal by cross-species nuclear transfer using post-mortem somatic cells. Nat Biotechnol 2001;19(10):962-4.

Mermillod P, Tomanek M, Marchal R, Meijer L. High developmental competence of cattle oocytes maintained at the germinal vesicle stage for 24 hours in culture by specific inhibition of MPF kinase activity. Mol Reprod Dev 2000;55(1):89-95.

Saikhun J, Kitiyanant N, Songtaveesin C, Pavasuthipaisit K, Kitiyanant Y. Development of swamp buffalo (Bubalus bubalis) embryos after parthenogenetic activation and nuclear transfer using serum fed or starved fetal fibroblasts. Reprod Nutr Dev 2004;44(1):65-78.

Spindler RE, Huang Y, Howard JG, Wang P, Zhang H, Zhang G, et al. Acrosomal integrity and capacitation are not influenced by sperm cryopreservation in the giant panda. Reproduction 2004;127:547-56.

Vacková I, Engelova M, Marinov I, Tomanek M. Cell cycle synchronization of porcine granulosa cells in G1 stage with mimosine. Anim Reprod Sci 2003;77(3-4):235-45.

Vindelov LL, Christensen IJ, Nissen NI. A detergent-trypsin method for the preparation of nuclei for flow cytometric DNA analysis. Cytometry 1983;3(5):323-7.

Williams JB, Shin T, Liu L, Flores-Foxworth G, Romano J, BlueMcClendon A, et al. Cloning of exotic/endangered species: desert bighorn sheep. Methods Mol Biol 2006;348:169-82. 